\title{
Energy retrofit of historic timber-frame buildings- hygrothermal monitoring of building fabric
}

\author{
C. J. Whitman, O. Prizeman, J. Gwilliam \\ Welsh School of Architecture, Cardiff University, Cardiff, UK \\ P. Walker, A. Shea \\ BRE Centre for Innovative Construction Materials, Department of Architecture \& Civil Engineering, \\ University of Bath, Bath, UK
}

Authors' Post Print copy pre-final proofs.

Raymond Lemaire International Centre for Conservation Series (CRC Press / Balkema of the Taylor\&Francis Group)

ABSTRACT: In line with its aim to decarbonize the EU's building stock by 2050, the May 2018 amendment to the Energy Performance of Buildings Directive calls for "research into... the energy performance of historic buildings... while also safeguarding and preserving cultural heritage." To date in the UK, research in this field has focused on solid masonry construction. The research in this paper explores the previously under-researched retrofit of historic timber-framed buildings. In situ monitoring highlights that in some instances, the combination of incompatible materials, flawed detailing, poor workmanship and lack of controlled ventilation can facilitate biological attack. Digital hygrothermal simulations suggest that orientation, climatic conditions and infill material all significantly influence hygrothermal behavior, however, no prolonged periods of conditions favorable to biological decay were identified. Initial monitoring of test panels under laboratory conditions supports these results, however further long term monitoring is required and is currently underway, funded by Historic England.

\section{INTRODUCTION}

Energy retrofits have been identified as a key action to decarbonize the UK's building stock and improve hygrothermal comfort (DECC, 2014, OJEU, 2018). When undertaken with sufficient knowledge and consideration, the energy retrofit of historic buildings can be successfully achieved (Historic England, 2012). However, aesthetic, philosophical and technical issues must be fully understood in order to avoid unintended consequences (ibid.). As stated by the European Standard BS EN 16883 Conservation of Cultural Heritage - Guidelines for improving energy performance of historic buildings "[the] challenge is to reduce energy demand and greenhouse gas emissions without unacceptable effects on the heritage significance of the existing built environment" (British Standards Institution, 2017). To achieve this goal the Standard presents a systematic approach to facilitate the decision-making process (Figure 1). However, a key stage, mentioned in the Standard's text but not included in the original diagram, is the need for postoccupancy evaluation and feedback to close the loop. It is therefore essential for academic research to actively monitor and assess both current and future retrofit solutions for the historic built environment.

Research in the UK in this field has so far focused on the predominant solid masonry construction (Baker

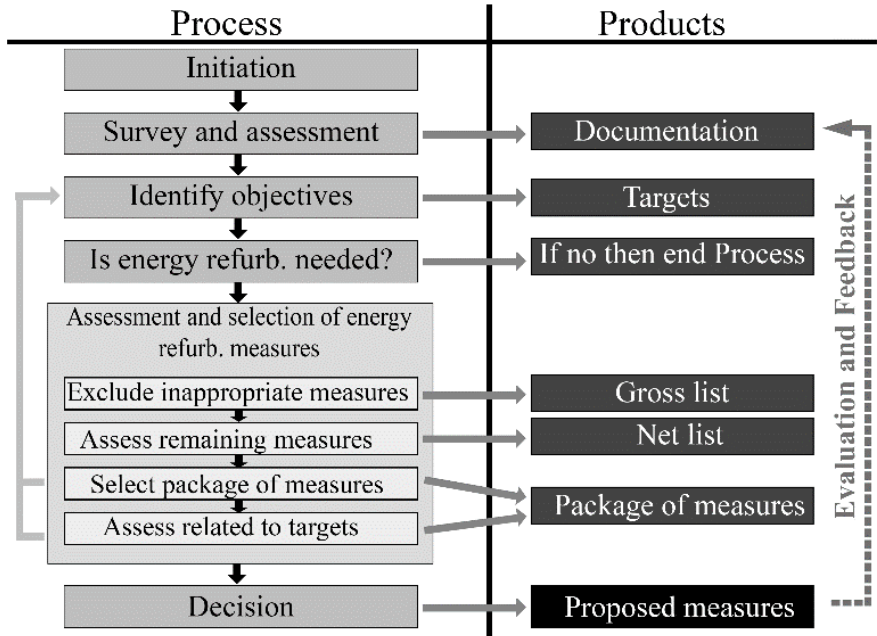

Figure 1. Flow chart showing procedure proposed by BS EN 16883. Source: based on (British Standards Institution, 2017) amended by author to include evaluation and feedback. and Rhee-Duverne, 2015, Currie et al., 2013, Gandhi et al., 2012), with little research covering the 68,000 historic timber-framed buildings that form an integral part of the UK and specifically England's cultural identity (Whitman, 2017). This paper explores this previously under-researched area.

\subsection{UK Historic Timber-Framed Construction}

Archaeological evidence of timber construction can be found in the UK dating back to Neolithic times 
(Hillam et al., 1990). One of the oldest timber buildings still standing, the church of St. Andrews, Greensted-juxta-Ongar, Essex, dates from the late $11^{\text {th }}$ to early $12^{\text {th }}$ century AD. This building with its walls of solid half trunks is however not representative of the majority of timber buildings constructed in the UK from Mediaeval times until the late $18^{\text {th }}$ century, which employed a timber frame with solid infill panels, the frame often exposed both internally and externally (Figure 2).

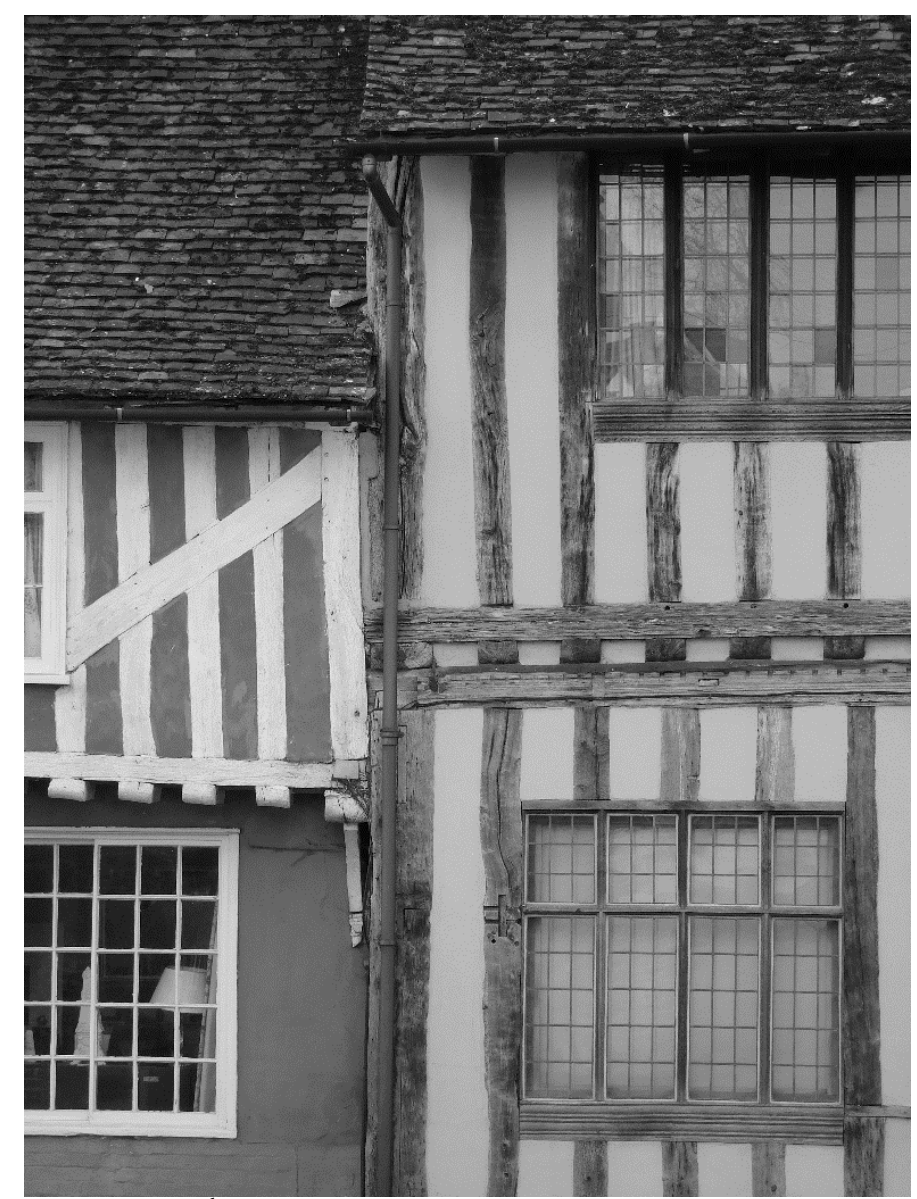

Figure $2.15^{\text {th }}$ century exposed timber-frames, Church Street, Lavenham, Suffolk, UK. Source (Whitman, 2017).

Infill panels were traditionally often of wattle-anddaub a framework of thin timber members (wattlework) covered by an earthen render (daub). Other historic infills include lath and plaster and brick nogging (Harris, 2010). Where these historic infill materials survive, their conservation should be paramount. However, where they are beyond repair, have already been replaced with inappropriate materials or where their renewal is required due to conservation of the historic timber frame, there exists the opportunity to replace them with materials with improved thermal performance (Historic England, 2016).

A key concern with the energy retrofit of historic timber-framed buildings is the risk of elevated moisture content, increasing the potential for insect attack and fungal decay (ibid). This paper presents research that begins to assess this risk with relation to the installation of replacement of infill panels.

\section{DESCRIPTION OF THE RESEARCH}

In order to explore the impact of replacement infill panels as an energy retrofit action for historic timberframed buildings in the UK, a variety of methodological techniques were applied. These were, in situ monitoring, digital simulation and laboratory testing. There follows details of the methodologies employed and a summary of the results obtained.

\subsection{In Situ Monitoring}

In situ hygrothermal monitoring was undertaken at five historic timber-framed buildings in the UK. The case studies were selected to represent a variety of retrofit solutions, ownership models and uses (Table 1). Three of the case studies were located in Herefordshire (1-3) and two in East Anglia (4\&5), both areas with a high concentration of the UK's surviving historic timber-frame buildings.

Table 1. Summary of case studies

\begin{tabular}{|l|l|l|l|l|}
\hline No. & Age & Use & Ownership & Retrofit \\
\hline 1 & $\mathrm{C}^{\text {th }}$ & Holiday let & Private & Extensive \\
\hline 2 & $\mathrm{C} 16^{\text {th }} 9^{\text {th }}$ & Dwelling & Charity & Partial \\
\hline 3 & $\mathrm{C} 17^{\text {th }}$ & Commercial & Charity & Extensive \\
\hline 4 & $\mathrm{C} 14^{\text {th }}$ & Dwelling & Private & None \\
\hline 5 & ${\mathrm{C} 16^{\text {th }}}^{\mid}$ & Dwelling & Private & Extensive \\
\hline
\end{tabular}

In summary, the retrofits of each case study are as follows; case study 1 had a mixture of replacement infill panel details, including some with traditional wattleand-daub and others with a multi-foil insulation, in addition to underfloor heating with a ground source heat pump; case study 2 had increased roof insulation and secondary glazing, with no changes made to the external walls; case study 3 had replacement panel infills of woodfibre and woodwool following the detail published by Historic England (McCaig and Ridout, 2012 p.325); case study 4 had no retrofit but is undergoing 'conservative repair' in line with the ethos of the Society for the Protection of Ancient Buildings (SPAB); and case study 5 had replacement infill panels of rigid polyisocyanurate (PIR) boards finished with gypsum plasterboard, roof insulation and double glazing.

Monitoring included U-value measurements following BS ISO 9869-1:2014 (British Standards Institution, 2014), thermography following best practice guidance (Hart, 1991, Young, 2015), pressure

Table 2. Comparison of U-values measured in situ according to BS ISO 9869-1:2014 and those calculated according to BS EN ISO 6946:2007. (Note: No in situ monitoring was possible at case study 2 due to personal circumstances of the resident) 


\begin{tabular}{lllll}
\hline $\begin{array}{c}\text { Case } \\
\text { Study }\end{array}$ & Panel build-up & $\begin{array}{l}\text { Measured } \\
\mathrm{U} \text {-value }\left(\mathrm{W} / \mathrm{m}^{2} \mathrm{~K}\right)\end{array}$ & $\begin{array}{l}\text { Calculated } \\
\mathrm{U} \text {-value }\left(\mathrm{W} / \mathrm{m}^{2} \mathrm{~K}\right)\end{array}$ & $\begin{array}{l}\text { Difference Measured to } \\
\text { calculated }\left(\mathrm{W} / \mathrm{m}^{2} \mathrm{~K}\right)\end{array}$ \\
\hline 1. & Original lime plaster on oak lath & 2.21 & 2.40 & 0.19 \\
& New wattle-and-daub & 2.88 & 2.99 & 0.11 \\
& Multi-foil insulation & 0.66 & 0.41 & -0.25 \\
3. & Woodfibre+ PIR internal lining & 0.11 & 0.13 & 0.02 \\
& Woodfibre+Mineral wool internal lining & 0.11 & 0.17 & 0.06 \\
4. & Pargeted with presumed wattle-and-daub infill & 0.64 & 1.79 & $\mathbf{1 . 1 5}$ \\
5. & Rigid PIR Insulation and Gypsum plasterboard & 1.72 & 0.92 & $\mathbf{- 0 . 8}$ \\
\hline
\end{tabular}

testing according to BS EN ISO 9972:2015 (British Standards Institution, 2015), measurements of internal hygrothermal comfort using TinyTag Ultra 2 TGU-4500 sensors and simplified occupant questionnaires (Nichol et al., 2012). Timber moisture content was also monitored at two of the case studies $(2 \& 5)$ using electrical resistance measurements.

\subsubsection{Results}

The use of modern insulation materials should improve the thermal performance of the infill panels, however the measured U-values were often lower than those calculated (Table 2). This discrepancy can be attributed to the thermal bridging of the exposed timber-frame and poor detailing especially at the junction between frame and infill. At case study 4 the large discrepancy between measured and calculated U-values may be due either to incorrect assumptions regarding the wall build-up or the possible higher thermal performance of traditional building materials that has also been encountered by other researchers (Rye et al., 2012). However at case study 5, where the replacement infill detail achieved only $53 \%$ of the calculated U-value, this is principally due to poor design and installation of the replacement panel infill detail (Whitman et al., 2018b). Thermographic surveys (Figure 3 ) highlight the lack of hermeticity between infill and timber-frame, leading to a high air change rate and associated increased heat loss. This was confirmed through pressure testing, with an air permeability index of $19 \mathrm{~m} / \mathrm{h} \cdot \mathrm{m}^{2}$.

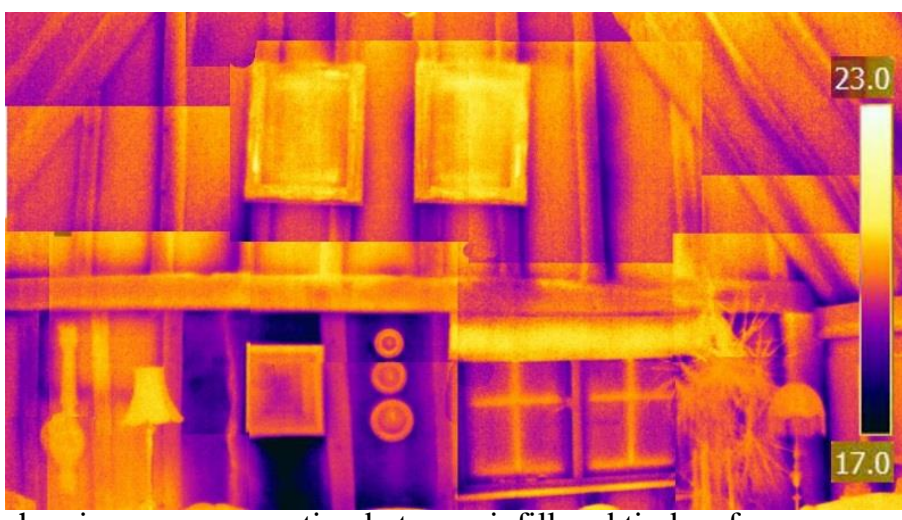

showing poor connection between infill and timber-frame.

Measurements of timber moisture content and temperature at the same case study showed that the use of non-vapour permeable materials, in conjunction with the poor detailing, had led to the creation of hygrothermal conditions that would facilitate biological attack, with one location providing conditions favourable to deathwatch beetle (Xestobium rufovillosum) for 99\% of the monitoring period (Whitman et al., 2018b). Favourable conditions were also identified for house longhorn beetle (Hylotrupes bajulus), dry rot (Serpula lacrymans) and cellar rot (Coniophora puteana), although with lesser periods of duration (ibid.). The potential for fungal decay further increases the risk posed by insect attach as both the deathwatch and house longhorn beetles will only inhabit wood that has already been damaged by decay.

In case study 2 , measurements pre and post-retrofit showed an increase in timber moisture content due to the retrofit actions increasing airtightness, without due regard to the provision of controlled ventilation. This highlights that whilst increased airtightness is required to improve these buildings' thermal performance, sufficient controlled ventilation must also be designed to manage internal relative humidity, especially in spaces with moisture sources such as bathrooms and kitchens.

The monitoring of internal hygrothermal conditions at all five case studies showed poor comfort conditions despite improvements to their external envelopes (Figure 4).

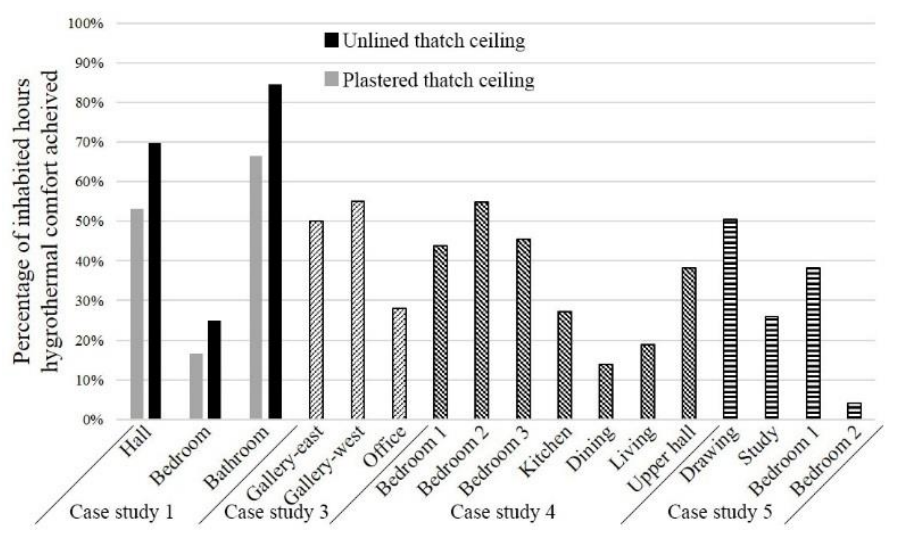

Figure 4. Percentage of inhabited hours measured where hygrothermal comfort was achieved.

Influencing factors include poor airtightness, incoherent retrofit strategies and inadequate, inefficient heating. Despite this, the results of simplified occupant questionnaires and semi structured interviews at three case studies $(1,2 \& 5)$ showed that occupants' ther- 
mal perceptions often contradicted the measured results, with their comments suggesting that their desire to live in these historic properties led to an acceptance of a lower thermal comfort threshold. This emotional response to heritage and its influence on occupant comfort and satisfaction presents an interesting area requiring further research.

\subsection{Digital Energy Demand Simulations}

Digital simulations of the energy demand of the five aforementioned case studies were undertaken using the software DesignBuilder Version 4.2.0.54, a graphical interface for the dynamic simulation engine EnergyPlus DLL v8.1.0.009 (Design Builder, 2014). Climate files were created for each site using the software Meteonorm version 6.1 using the time period 1996-2005.

For each case study each of the individual retrofit actions were simulated separately in order to assess their specific impact on the building's heating demand. In addition, simulations of the combined effect of multiple retrofit actions, both those applied in reality and hypothetical scenarios, thereby allowing the assessment of the current and future potential performance of these buildings.

\subsubsection{Results}

For case study 1 the results showed that the mixture of replacement panel infills as built has little effect on the energy demand with only a $3 \%$ reduction as compared to a hypothetical scenario of all the infill panels being the surviving lime plaster on oak lath. In reality many of the original panels had already been lost or required replacement due to repair work to the surrounding timber frame. However, if this had not been the case, historic fabric could have been lost for little gain in energy efficiency. The results did however show that the simple act of lime plastering the previously unlined exposed thatch ceiling, reduced the air change rate by approximately $50 \%$, resulting in a significant impact on the energy demand with a reduction of $36 \%$.

At case study 2, the introduction of secondary glazing resulted in a reduction of $10 \%$ in the heating energy demand by simultaneously improving the thermal performance of the fenestration and the airtightness. This when combined with the roof insulation resulted in an overall reduction of $34 \%$. The simulation of a hypothetical scenario replacing all the current infill panels (predominantly $20^{\text {th }}$ century concrete block, with some surviving wattle-and-daub) showed only a $9 \%$ improvement. Given this minimal improvement, it is questionable if this should be attempted in the future due to the major disruption to the building's occupant and the potential loss and damage to the historic fabric.

The simulations for case study 3 again indicated a limited impact of the replacement of the infill panels with woodfibre and woodwool, in conjunction with additional partial internal lining, with a reduction in heating energy demand of $12 \%$. If instead $20 \mathrm{~mm}$ of woodfibre insulation had been installed above the $17^{\text {th }}$ century plastered ceiling then a reduction of $17 \%$ could have been achieved. It is understandable the conservation architect's reluctance to undertake work directly related to this element which is perhaps the building's most significant heritage asset. However, thermography undertaken during the in-situ monitoring highlighted large differences between the now insulated walls and the uninsulated ceiling, raising concern over the potential concentration of condensation on the latter. This highlights the complex and difficult decisions faced by those engaged in the energy retrofit of historic buildings and sustainable building conservation.

For case study 4 a heating demand of $113 \mathrm{kWh} / \mathrm{m}^{2}$ was simulated. This had increased from $97 \mathrm{kWh} / \mathrm{m}^{2}$ in 2012 when the house had previously been pressure tested (Hubbard, 2012). The deterioration in airtightness had resulted from the removal of impermeable $20^{\text {th }}$ century internal finishes as part of the conservative repair the building is currently undergoing. It is hoped that when this work is completed and new more appropriate finishes have been installed that the airtightness will improve and hence result in a reduction in the energy demand. Assuming no improvement in airtightness, a $25 \mathrm{~mm}$ layer of woodfibre insulation applied as internal lining to the walls would see a potential reduction of $12 \%$. However, there is concern over the impact of this insulation on the elaborate $17^{\text {th }}$ century exterior pargetting, probably the buildings most significant feature. Modelling using THERM ${ }^{\circledR}$ version 7.5 showed that the temperature of the external surface of the pargetting would drop by $0.5^{\circ} \mathrm{C}$ with the introduction of the insulation, thereby increasing the risk of frost damage. Potentially a more appropriate solution would be to insulate the roof and exposed floors which combined could result in a reduction of $14 \%$.

Finally, for case study 5 , due to the previously mentioned poor thermal performance of the badly designed and installed replacement infill panels, it is possible that the heating energy demand increased by $1 \%$ as a result of the retrofit. It may however be reasonable to suppose that the original lath and plaster infill panels provided a more hermetic seal between panel and timber-frame and so possibly the increase in heating demand may be even higher. The current owner and their architect now intend to replace the rigid PIR insulation and gypsum plasterboard with sheep's wool insulation held between lath and plaster. It is hoped that this will result in a heating demand of $63 \mathrm{kWh} / \mathrm{m}^{2}$ a reduction of $32 \%$ from the current situation.

Both the in situ measurements and the energy demand simulations demonstrate that if well designed and installed, the thermal upgrading of the walls of 
timber-framed historic buildings can be beneficial but only when considered as part of a whole house approach, with improvements to airtightness seeing the greatest impacts. Conversely, when poorly designed and installed, replacement infill panels have the potential to not only reduce the energy efficiency of the building but also put its historic fabric at risk.

\subsection{Digital hygrothermal simulations}

In order to study the risk of increased moisture content arising from replacement panel infills, digital hygrothermal simulations with WUFI ${ }^{\circledR}$ Pro 5.3 were undertaken. Thirteen replacement panel infill details proposed by current guidance (Historic England, 2016, Reid, 1989, McCaig and Ridout, 2012) were simulated in six geographical locations (Suffolk, Cambridgeshire, Kent, Devon, Herefordshire and Cumbria (Figure 5)), representing the principal climates where timber-framed buildings are to be found in England (Whitman, 2017).

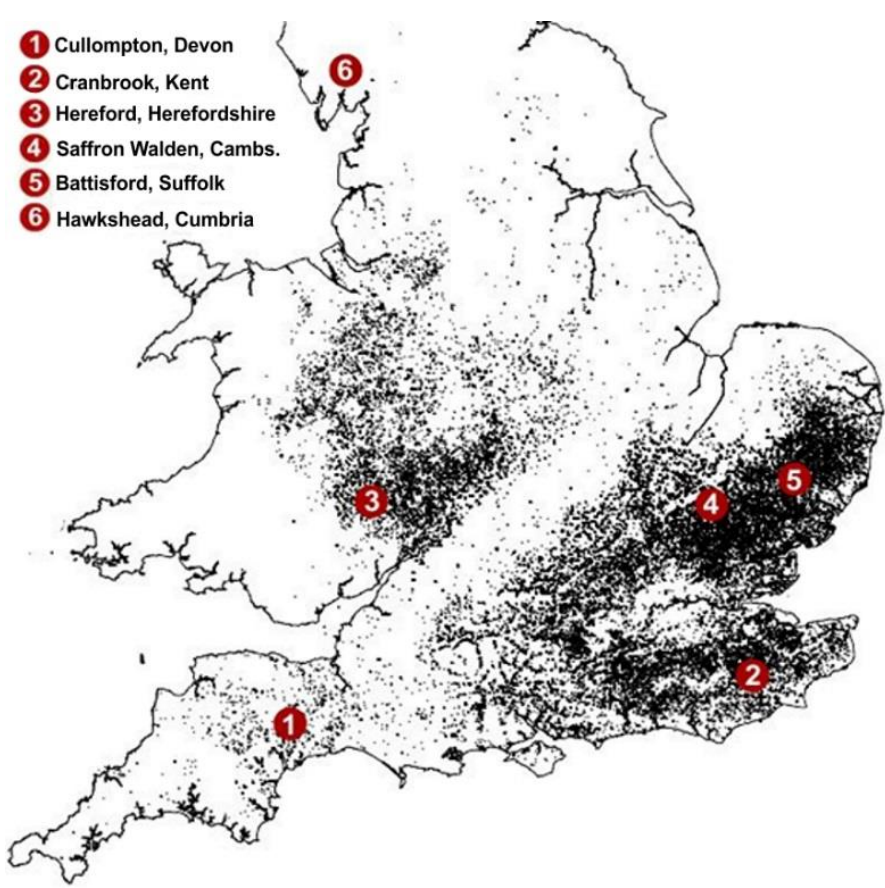

Figure 5. Geographical locations used for WUFI® Pro5.3 simulations of replacement infill panel details.

\subsubsection{Results}

The results suggest that orientation, climatic conditions and infill material all significantly influence the moisture content, however, no prolonged periods of hygrothermal conditions favourable to biological decay agents were identified (Whitman et al., 2015). Those instances of favourable conditions that did occur were sporadic and limited to fewer hours than those required for the gestation of both insects and fungi.

The orientation with the highest risk was south. Although it had been assumed that the prevailing patterns of wind driven rain would prejudice a south west orientation, the increased exposure to direct solar gain of panels facing due south would appear to be more influential in creating the warm damp conditions favourable to biological attack.

Surprisingly the location with the highest risk was not that with the highest rainfall, Cumbria, but rather Suffolk, where higher rainfall occurs during summer months, coinciding with warmer temperatures. Although there currently exists some debate as to whether climate change will lead to increased summer rainfall, overall the predictions point to lower precipitation levels in the summer (Environment Agency, 2014), however, there are suggestions that there may be an increase in hourly rainfall intensities due to convection induced precipitation (thunderstorms) (Kendon et al., 2014 p.570). If so then the climate seen in Suffolk may become more common across the country, thereby increasing the risk of biological attack. This is an interesting area for further research.

The replacement panel infill detail with the highest risk of biological attack would appear to be hemplime due to the high initial moisture content of this construction. The drying time for built in moisture can be significantly reduced if work takes place at the beginning of the summer. This highlights the need for informed programming of such construction work.

It must however be acknowledged that these simulations represent idealised constructions with homogenous layers, rather than the heterogeneous reality, and that material data are limited for historic materials.

\subsection{Physical Test Panels}

Given the limitations of the digital simulations, the interstitial hygrothermal monitoring of physical test panels was also undertaken (Figure 6).

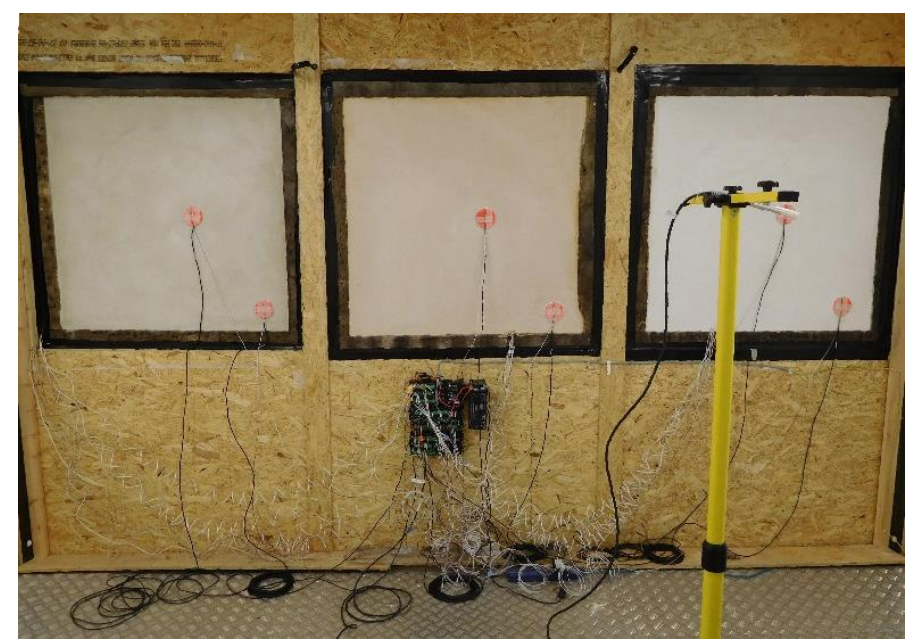

Three test infill panels $1020 \mathrm{~mm} \times 1020 \mathrm{~mm}$ x 100mm

Figure 6. Panels in climate chamber. View from "internal" chamber.

(L x W x D) were constructed within reclaimed oak frames. The dimensions were defined following a review of a representative sample of 100 historic timber-framed buildings in the UK. Dynamic Vapour 
Sorption (DVS) undertaken on oak samples felled in the 17th, 19th and 21st centuries showed that age did affect vapour sorption with the older samples absorbing less moisture (Demonstration \& Contract Testing Services, 2015). Reclaimed oak was therefore used for the panel frames.

Following a review of details proposed by current guidance, the chosen infill materials were wattle-anddaub, expanded cork, and a detail using wood fibre and wood wool as suggested by Historic England (McCaig and Ridout, 2012). The panels were mounted as part of a dividing wall between two climate-controlled chambers at the University of Bath's Building Research Park.

Temperature and moisture content were monitored in the centre of the panel and at the interface between infill and oak frame at depths of $10 \mathrm{~mm}, 50 \mathrm{~mm}$ and $90 \mathrm{~mm}$. Results were compared with digital simulations using WUFI® Pro 5.3 and WUFI 2D using measured climatic data.

\subsubsection{Results}

Under extreme steady state conditions, sustained for three weeks, interstitial condensation was measured in the woodfibre/woodwool panel (Whitman et al., 2018a). However this did not reoccur during a following fortnight of cyclical dynamic conditions (ibid.). Whilst the digital simulations did successfully predict this condensation, discrepancies were identified both between measured and simulated data and between simulation methods. Further long term monitoring is now being funded by Historic England.

\section{CONCLUSIONS}

- The in situ monitoring and digital energy simulations have shown that modern insulation has the potential to improve the thermal performance of historic timber-framed buildings, although thermal bridging by the frame and poor detailing can significantly reduce their effectiveness. Those retrofit actions with the greatest impact on reducing energy demand were related to improving airtightness. However, these must always be undertaken whilst providing adequate controlled ventilation to avoid the increase in internal relative humidity and moisture content of internal finishes as seen in case study 2 .

- Whilst retrofit solutions were shown to improve the performance of individual building elements, there was often a negligible increase in overall energy efficiency and hygrothermal comfort conditions. However, the measured conditions did not always correlate with occupants' thermal perceptions. This may suggest a possible positive influence of the occupants' emotional connection to the buildings. This presents an interesting area for future research.
- The in situ monitoring at case study 5 highlighted that the use of non-vapour permeable materials and poor detailing can increase the risk of biological attack. This was confirmed by the digital hygrothermal simulation which concluded that panel orientation, climatic conditions and infill material all significantly influence the moisture content, with warm damp climates being most at risk. Given the possible increase in convection induced summer precipitation and warmer summer temperatures, this is an area requiring further research.

- The monitoring of physical test panels showed that under extreme conditions interstitial condensation has been observed to occur, however discrepancies exist between simulated and measured data. Further research over a longer period is therefore required. A test cell that will allow the monitoring over a minimum of two years, of four panel infill details, is currently under construction funded by Historic England.

- Together, the research presented in this paper demonstrates the complexities of the energy retrofit of historic timber-framed buildings and the need for monitoring and simulation to inform the decisions of those undertaking this work. By doing so it is possible to both learn from past mistakes and achieve the best outcomes with the minimal loss of historic fabric.

\section{ACKNOWLEDGEMENTS}

The authors wish to thank the owners of the case study buildings for allowing access. The monitoring of physical test panels was made possible by the APT Martin Weaver Scholarship, in addition to the help of Royston Davies Conservation Builders and Ty Mawr Lime Ltd.

BAKER, P. \& RHEE-DUVERNE, S. (2015) A Retrofit of a Victorian Terrace House in New Bolsover a Whole House Thermal Performance Assessment. Historic England.

BRITISH STANDARDS INSTITUTION (2014) BS ISO 9869-1:2014 Thermal insulationBuilding elements- in situ measurement of thermal resistance and thermal transmittance Part 1: Heat flow meter method.

BRITISH STANDARDS INSTITUTION (2015) BS EN ISO 9972:2015 Thermal performance of buildings - determination of air permeability of buildings - fan pressurization method. British Standards Institution.,.

BRITISH STANDARDS INSTITUTION (2017) BS EN 16883 Conservation of Cultural Heritage - Guidelines for improving energy performance of historic buildings. BSI.

CURRIE, J., WILLIAMSON, J. B. \& STINSON, J. (2013) Technical Paper 19: Monitoring thermal upgrades to ten traditional properties. Glasgow, Historic Environment Scotland,. 
DECC (2014) UK National Energy Efficiency Action Plan London.

DEMONSTRATION \& CONTRACT TESTING SERVICES (2015) Customer ReportSamples WSA17, WSA19 \& WSA21. Surface Measurement Systems Ltd.

DESIGN BUILDER (2014) Design Builder Help 4.2.

GANDHI, K., JIANG , S. \& TWEED, C. (2012) Field Testing of Existing Stone Wall in North Wales Climate. SusRef: Sustainable Refurbishment of Building Facades and External Walls. Cardiff University.

HARRIS, R. (2010) Discovering Timber-Framed Buildings, Oxford, UK, Shire Publications.

HART, J. M. (1991) Practical guide to infra-red thermography for building surveys. Bracknell, UK, Building Research Establishment.

HILLAM, J., GROVES, C., BROWN, D., BAILLIE, M., COLES, J. \& COLES, B. (1990) Dendrochronology of the English Neolithic. Antiquity, 64, 210-220.

HISTORIC ENGLAND (2012) Energy Efficiency and Historic Buildings: Application of Part L of the Building Regulations to historic and traditionally constructed buildings (Revised 2012). IN ENGLISH HERITAGE. (Ed. Online. UK, English Heritage.

HISTORIC ENGLAND (2016) Energy Efficiency and Historic Buildings: Insulating TimberFramed Walls. IN HISTORIC ENGLAND (Ed.

HUBBARD, D. (2012) Air permeability testing and thermographic survey: 27 Church Street, Saffron Walden., ArchiMetrics.

MCCAIG, I. \& RIDOUT, B. (2012) English Heritage practical building conservation- Timber, London; Farnham, Surrey; Burlington, VT, English Heritage ; Ashgate.

NICHOL, F., HUMPHREYS, M. \& ROAF, S. (2012) Adaptive thermal comfort: Principles and practice, Abingdon, Oxfordshire, UK, Routledge.

OJEU (2018) DIRECTIVE (EU) 2018/844 OF THE EUROPEAN PARLIAMENT AND OF THE COUNCIL of 30 May 2018 amending Directive 2010/31/EU on the energy performance of buildings and Directive 2012/27/EU

on energy efficiency. Official Journal of the European Union.

REID, K. (1989) Panel Infillings to timber-framed buildings. IN SOCIETY FOR THE PROTECTION OF ANCIENT BUILDINGS. (Ed. London, UK.

RYE, C., SCOTT, C. \& HUBBARD, D. (2012) THE SPAB RESEARCH REPORT 1. U-Value Report. Revision 2 ed., Society for the Protection of Ancient Buildings.

WHITMAN, C. J. (2017) The distribution of historic timber-framed buildings in the UK and the impacts of their low energy retrofit. Cardiff University.
WHITMAN, C. J., PRIZEMAN, O., GWILLIAM, J., SHEA, A. \& WALKER, P. (2018a) Physical Monitoring of Replacement Infill Panels for Historic Timber-Framed Buildings in the UK. Passive and Low energy Architecture (PLEA) 2018. Hong Kong.

WHITMAN, C. J., PRIZEMAN, O., GWILLIAM, J. \& WALKER, P. (2018b) The impact of modernization of a 16th century timberframed farmhouse, Suffolk, UK. Energy Efficiency in Historic Buildings (EEHB) 2018. Visby, Sweden.

WHITMAN, C. J., PRIZEMAN, O. \& WALKER, P. (2015) Interstitial Hygrothermal Conditions of Low Carbon Retrofitting Details for Historic Timber-framed Buildings in the UK. Passive and Low Energy Architecture (PLEA). Bologna.

YOUNG, M. (2015) Thermal Imaging in the Historic Environment. Short Guide. Historic Environment Scotland,. 